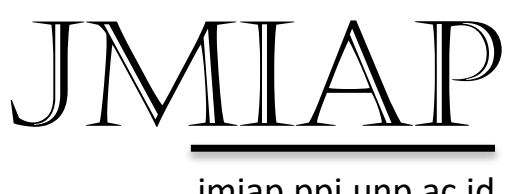

jmiap.ppj.unp.ac.id

\title{
PENGARUH PELATIHAN KERJA APARATUR PEMERINTAH NAGARI TERHADAP PENGELOLAAN KEUANGAN NAGARI DI KABUPATEN TANAH DATAR
}

\section{Herlinda Novita Wardani}

Jurusan Administrasi Publik, Fakultas Ilmu Sosial, Universitas Negeri Padang herlindanovitawardani@gmail.com

\begin{abstract}
The purpose of this study was to analyze the effect of job training on the performance of nagari government apparatus in nagari financial management in Tanah Datar Regency. The background of this study was carried out because there was an indication of the lack of proper material and inadequate facilities received by the nagari government aapparatus in nagari financial management in Tanah Datar Regency. This study uses a quantitative approach with population of this study was all nagari government apparatus, which numbered 600 people. Sample in this study was consisted of 248 nagari government apparatus determined with Slovin formula. Besides, sample in this study was determined through Multistage Random Sampling technique. The data was collected through questionnaires using Likert scale measurement. The data was analyzed with multiple linear regression tests. The results of this study showed that the job training variable (simultaneously and partially) influenced the performance of nagari government apparatus in financial management in Tanah Datar Regency. Thus it could be concluded that job training had a significant effect on the performance of nagari government apparatus in nagari finance management in Tanah Datar Regency.
\end{abstract}

Keywords: Job training, job performance, nagari financial management 
Pendahuluan

Upaya pemerintah pusat maupun daerah dalam pelaksanaan pengelolaan keuangan bertujuan untuk memastikan terlaksananya pembangunan. Pengelolaan keuangan yang dilakukan oleh pemerintah diharapkan dikelola secara transparan dan dapat dipertanggungjawabkan kepada masyarakat sesuai dengan ketentuan yang berlaku. Muhammad Arif (2007: 32) pengelolaan keuangan daerah adalah semua kegiatan yang berkaitan dengan perencanaan, penganggaran, penatausahaan, pelaporan, pertartanggungjawaban dan pengawasan keuangan desa.

Setelah disahkannya UndangUndang Nomor 6 Tahun 2014 Tentang Desa, desa diberikan kewenangan untuk mengurus tata pemerintahannya sendiri dan dapat melaksanakan pembangunan sehingga kesejahteraan dan kualitas hidup masyarakat desa meningkat. Selain itu pemerintah desa seharusnya lebih mandiri dalam mengelola keuangan, kekayaan milik desa dan sumber daya alam yang ada. Maka untuk itu pemerintah desa sepatutnya dapat menerapkan prinsip akuntabilitas dan transparansi dalam penyelenggaraan pemerintahan yang mana semua itu harus dipertanggungjawabkan nantinya kepada masyarakat sesuai dengan ketentuan yang ada.

Selanjutnya, dalam UndangUndang Nomor 23 Tahun 2014 Tentang Pemerintah Daerah dijelaskan bahwa dana desa/nagari dianggarkan oleh pemerintah untuk membiayai penyelenggaraan pemerintah, pembangunan, pembinaan masyarakat dan pemberdayaan masyarakat desa berdasarkan kewenangan dan kebutuhan
Email : jianfis.unp@gmail.com

Vol.2 No.1 Tahun 2019 desa dan ketentuang yang berlaku. Dengan demikian dapat dipahami bahwa keuangan nagari dikelola dengan sebaikbaiknya secara sistematik dan memperhatikan kegunaannya untuk kesejahteraan masyarakat.

Kemudian dalam Peraturan Bupati Kabupaten Tanah Datar Nomor 11 Tahun 2014 Tentang Pedoman Pengelolaan Keuangan Desa Pasal 2 Ayat 1 dijelaskan bahwa keuangan desa dikelola berdasarkan asas-asas transparansi, akuntabel, partisipatif serta tertib dan disiplin anggaran. Selanjutnya batas masa pengelolaan keuangan desa mulai tanggal 1 Januari sampai 31 Desember. Walaupun demikian, di lapangan masih ditemukan adanya penyelewengan yang muncul dalam proses pengelolaan keuangan nagari di Kabupaten Tanah Datar.

Salah satu contohnya adalah di Nagari Barulak, masalah utamanya Walinagari sebagai penyelenggara pengelolaan keuangan nagari tidak terbuka dalam pelaporan keuangan nagari sehingga banyak masyarakat yang mempertanyakan keuangan nagari. Senada dengan itu sesuai dengan yang disampaikan oleh Anggit selaku Koordinator LSM PENJARA (Pemantau Kinerja Aparatur Negara) untuk Nagari Sungayang, bahwa memang diduga adanya indikasi kecurangan, mulai dari tidak adanya transparansi aset nagari oleh pemerintah seperti kebun nagari dan dana DAUN (Dana Alokasi Umum Nagari) yang sampai saat ini tidak ada kejelasannya sama sekali kepada masyarakat (Sumber berita dari Warta Andalas, 2015 di akses tanggal 23 April 2018).

Selanjutnya, berdasarkan hasil wawancara dengan Bapak Afdalisman selaku Sekretaris Nagari Saruaso 
Kecamatan Tanjung Emas pada bulan Mei 2018 selama beliau mengikuti pelatihan terkait pengelolaan keuangan nagari fasilitas yang diberikan kurang memadai, hanya difasilitasi buku dan pena. Disamping itu Bendahara Nagari Sumpur Kecamatan Batipuah Selatan juga menjelaskan bahwa waktu pelaksanaan pelatihan yang diadakan oleh Badan Keuangan Daerah tidak tepat pada waktunya sehingga sulit untuk menyesuaikannya dengan pekerjaan kantor yang sedang menumpuk. Dalam pelaksanaan pelatihan yang diikuti banyak dari aparatur pemerintah nagari yang tidak mengerti dengan apa yang sedang mereka ikuti karena materi pelatihan yang diberikan tidak sesuai dengan apa yang dibutuhkan oleh aparatur pemerintah nagari.

Selain itu, berdasarkan hasil penelitian yang penulis temukan bahwa terdapat hasil penelitian yang menyatakan bahwa pelatihan kerja memiliki pengaruh signifikan terhadap kinerja seperti hasil penelitian yang dilakukan oleh Sugiarti dkk (2016) dengan judul Pengaruh Pelatihan Kerja terhadap Kinerja Karyawan Pada PT. Padma Ardya Aktuaria Jakarta, dengan hasil penelitian yang didapatkan bahwa pelatihan kerja memiliki pengaruh signifikan terhadap kinerja karyawan, kemudian penelitian oleh $\mathrm{Ni}$ Wayan (2017) meneliti Pengaruh Pelatihan terhadap Kinerja Karyawan Pada Lembaga Perkreditan Desa (LPD) Kabupaten Buleleng, hasil penelitian yang didapatkan bahwa pelatihan berpengaruh positif dan signifikan terhadap kinerja karyawan, selanjutnya penelitian Andi dkk (2017) meneliti Pengaruh Pelatihan, Disiplin dan Motivasi terhadap Kinerja Pegawai Pada Badan Pengelolaan Keuangan dan Asset
Daerah Provinsi Sulawesi Tengah, hasil penelitian menunjukkan bahwa pelatihan,disiplin dan motivasi memberikan pengaruh signifikan terhadap kinerja pagawai, dan terakhir ada juga terdapat hasil penelitian yang menyatakan bahwa pelatihan berpengaruh signifikan terhadap kinerja, berdasarkan penelitian yang dilakukan oleh Daniel (2013) meneliti Pengaruh Pelatihan Kerja dan Motivasi terhadap Kinerja Karyawan PT. Sucofindo (Persero) Surabaya, hasil penelitian membuktikan bahwa pelatihan kerja berpengaruh signifikan terhadap kinerja karyawan dibandingkan dengan motivasi.

Berdasarkan latar belakang masalah di atas, maka penulis telah melakukan penelitian di Kabupaten Tanah Datar tentang Pengaruh Pelatihan Kerja Aparatur Pemerintah Nagari terhadap Pengelolaan Keuangan Nagari di Kabupaten Tanah Datar. Penelitian ini merupakan intisari dari hasil penelitian skripsi dan bagian dari penelitian payung yang dilakukan oleh Syamsir (2017) dengan judul Model Pembinaan Aparatur Pemerintah Nagari dalam Pengelolaan Keuangan Nagari di Kabupaten Tanah Datar. Adapun rumusan masalahnya adalah “ Apakah terdapat Pengaruh Pelatihan Kerja Aparatur Pemerintah Nagari terhadap Pengelolaan Keuangan Nagari di Kabupaten Tanah Datar?".

\section{Tinjauan Kepustakaan}

\section{Pengelolaan Keuangan Desa/Nagari}

Dalam pengelolaan keuangan desa/nagari tidak hanya menyangkut perlunya peraturan yang mendukung, sarana dan prasarana, tetapi yang paling penting adalah adanya sumber daya 
manusia yang profesional dan komitmen yang dapat diandalkan. Dengan disahkannya Undang-Undang Nomor 6 Tahun 2014 Tentang Desa, maka pemerintah desa ikut mengelola keuangan dan dapat mempertanggungjawabkannya. Pada Pasal 1 Ayat 10 juga menjelaskan yang dimaksud dengan Keuangan Desa adalah hak dan kewajiban desa yang dapat dinilai dengan uang serta segala sesuatu berupa uang dan barang yang berhubungan dengan dilaksanakannya hak dan kewajiban desa.

Secara umum, peraturan yang mengatur tentang Pedoman Pengelolaan Keuangan Desa di Indonesia adalah Peraturan Menteri Dalam Negeri Nomor 113 Tahun 2014 Tentang Pedoman Pengelolaan Keuangan Desa, yang mana dalam Pasal 1 Ayat 6 dijelaskan bahwa pengelolaan keuangan desa merupakan seluruh kegiatan yang meliputi mulai dari perencanaan, pelaksanaan, penatausahaan, pelaporan dan pertanggungjawaban keuangan desa.

Selain itu, Pengelolaan keuangan Desa/Nagari juga diatur dalam Peraturan Pemerintah Nomor 47 Tahun 2015 Tentang Desa, bahwa realisasi keuangan nagari paling sedikit $70 \%$ (tujuh puluh per seratus) dari jumlah anggaran belanja Desa/Nagari digunakan untuk mendanai penyelenggaraan Pemerintahan Desa, pembangunan Desa, pembinaan masyarakat Desa dan pemberdayaan masyarakat Desa dan paling banyak 30\% (tiga puluh per seratus) dari jumlah anggaran belanja Desa digunakan untuk penghasilan tetap dan tunjangan Kepala Desa dan perangkat Desa, operasional pemerintahan Desa, tunjangan dan operasional Badan Permusyawaratan Desa serta insentif rukun tetangga dan rukun warga.
Email : ¡ianfis.unp@gmail.com

Vol.2 No.1 Tahun 2019

Menurut Rochmansyah Soleh (2015: 3) bahwa keuangan desa merupakan semua hak dan kewajiban desa yang dapat dinilai dengan uang serta semua yang berhubungan dengan pelaksanaan hak dan kewajiban tersebut. Selain itu sebagaimana diatur dalam Undang-Undang Nomor 17 Tahun 2003 Tentang Keuangan Desa dinyatakan bahwa keuangan desa pada dasarnya adalah sub system dari keuangan negara. Dalam Peraturan Menteri Dalam Negeri Nomor 113 Tahun 2014 Tentang Pedoman Pengelolaan Keuangan Desa di dalamnya dijelaskan bahwa pengelolaan keuangan desa dilakukan secara transparan, akuntabel, partisipatif, serta tertib dan disiplin anggaran.

Senada dengan itu menurut Murtiono Yusuf (2016: 13) adapun indikator untuk mengukur kinerja kepala desa dalam pelaksanaan pengelolaan keuangan desa antara lain:

1. Transparan yaitu prinsip keterbukaan yang membuat masyarakat untuk mengetahui dan mendapatkan akses informasi seluas-luasnya tentang pengelolaan keuangan desa atau APBDesa.

2. Akuntabel yaitu prinsip dari kewajiban seseorang untuk dapat mempertanggungjawabkan

pengelolaan dan pengendalian sumber daya dan pelaksanaan dan kebijakan yang dipercayakan kepadanya dalam rangka pencapaian tujuan yang telah ditetapkan.

3. Partisipatif yaitu pengelolaan keuangan desa harus memberikan ruang seluas-luasnya kepada msayarakat secara aktif terlibat dalam setiap tahapan proses pengeloaan keuangan desa.

4. Tertib dan Disiplin Anggaran yaitu mengandung makna APBDesa harus 
dikelola dengan tepat waktu dan tepat guna yang didukung dengan bukti-bukti administrasi yang dapat dipertanggungjawabkan dan berpedoman pada peraturan yang berlaku.

Untuk merealisasikan Peraturan Menteri Dalam Negeri Nomor 113 Tahun 2014 Tentang Pedoman Pengelolaan Keuangan Desa tersebut, maka Pemerintah Kabupaten Tanah Datar menetapkan dan mengesahkan Peraturan Bupati Kabupaten Tanah Datar Nomor 11 Tahun 2014 Tentang Pengelolaan Keuangan Nagari. Pasal 1 Ayat 22 dijelaskan bahwa Pejabat Pengelola Keuangan Nagari yang selanjutnya disebut PKK Nagari adalah Walinagari yang memiliki wewenang melaksanakan pengelolan APBNagari sekaligus bertindak sebagai Bendahara Umum Nagari (BUNagari). Selanjutnya pada Pasal 2 Ayat 1 juga dijelaskan pengelolaan keuangan nagari dikelola secara tertib, taat pada peraturan perundang-undangan, efektif, efisien, ekonomis, transparan dan bertanggungjawab dengan memperhatikan asas keadilan, kepatutan dan kemanfaatan untuk masyarakat.

Sedangkan menurut Peraturan Daerah Kabupaten Tanah Datar Nomor 4 Tahun 2008 Tentang Nagari pada Pasal 6 dijelaskan bahwa perangkat nagari terdiri atas sekretaris nagari dan perangkat nagari lainnya. Adapun perangkat nagari lainnya terdiri dari unsur staff sekretariat nagari yang memiliki lima urusan yaitu urusan umum, pembangunan, pemerintahan, perekonomian, kesejahteraan dan keuangan serta unsur jorong dan pelaksana teknis lapangan. Dengan demikian perangkat nagari yang seharusnya bekerjasama dalam melaksanakan pengelolaan keuangan nagari secara transparan, akuntabel, partisipatif serta tertib dan disiplin anggaran sesuai dengan Peraturan Menteri Dalam Negeri Nomor 113 Tahun 2014 Tentang Pedoman Pengelolaan Keuangan Desa.

\section{Kinerja dan Pelatihan}

Kinerja berasal dari bahasa inggris yaitu performance yang artinya prestasi kerja atau hasil kerja. Namun kinerja menurut Wibowo (2011: 34) sebenarnya memiliki arti yang sangat luas, tidak hanya prestasi kerja, tetapi termasuk juga bagaimana proses pekerjaan berlangsung. Sementara menurut Michael Amstrong dan Baron (dalam Emron Edison dkk, 2016: 190) kinerja itu sendiri merupakan hasil dari suatu proses yang mengarahkan dan diukur selama periode waktu tertentu sesuai dengan ketentuan dan kesepakatan yang sudah ditetapkan sebelumnya.

Menurut Campbell (dalam Mahmudi, 2015: 20) bahwa kinerja dipengaruhi oleh faktor pengetahuan, keterampilan yang diperoleh melaui pelatihan personel. Dari faktor-faktor tersebut yang mempengaruhi kinerja yang diungkapkan di atas dapat diketahui bahwa pelatihan merupakan faktor utama yang mempengaruhi kinerja. Senada dengan itu Anwar Prabu Mangkunegara (2011: 67-68) ada dua faktor yang mempengaruhi pencapaian kinerja yaitu faktor kemampuan dan faktor motivasi. Sedangkan menurut Irham Fahmi (2016: 194) kinerja dipengaruhi oleh faktor-faktor, yaitu pelatihan-pelatihan yang berbasis kompetensi, teknologi/mesin, metode/system.

Menurut Ivancevich (dalam Edy Sutrisno, 2009: 67) pelatihan adalah 
suatu usaha untuk meningkatkan kinerja karyawan dalam pekerjaannya sekarang atau dalam pekerjaan lain yang akan dijabatnya segera. Pelatihan yang baik tentu akan meningkatkan pengetahuan, kemampuan dan perilaku spesifik yang berkaitan dengan pekerjaan. Selanjutnya menurut Wexley dan Yulk (dalam Edy Sutrisno, 2009: 67) bahwa pelatihan dapat meningkatkan produktifitas dan kepuasan kerja. Sedangkan menurut Soekidjo Notoatmodjo (2009: 19) pelatihan adalah suatu perubahan yang dapat meningkatakan kemampuan dan sasaran karyawan dalam melakukan pekerjaan.

Menurut Rachmawati Ike Kusdyah (2008: 110) pelatihan adalah wadah lingkungan bagi karyawan, yang mana mereka mengetahui dan mempelajari sikap, kemampuan, keahlian, pengetahuan dan perilaku spesifik yang berhubungan dengan pekerjaan. Selain itu, menurut Edy Sutrisno (2009: 67) bahwa pelatihan berkaitan dengan keterampilan dan kemampuan yang diperlukan pada saat pekerjaan itu dilakukan, pelatihan berorientasi pada masa sekarang dan membantu karyawan dalam menguasai keterampilan dalam pekerjaannya.

Disamping itu, Husein Umar (2002: 130) mengemukakan bahwa ada enam komponen utama efektivitas pelatihan untuk dapat dijadikan indikator mengukur pelatihan yaitu:

1. Fasilitas

Dengan mengetahui keperluan akan sebuah pelatihan, sebagai bentuk langkah awal ditentukannya fasilitas pelatihan yang harus disediakan agar pelatihan berjalan dengan lancar.

2. Bahan pendukung

\section{Email : jianfis.unp@gmail.com}

Vol.2 No.1 Tahun 2019

Bahan pendukung atau sarana pendukung berguna untuk mengukur kelebihan suatu program, kelengkapan dan kondisi yang berguna sebagai umpan balik untuk menilai output yang dihasilkan.

3. Materi Pelatihan

Materi pelatihan berupa: pengelolaan (manajemen), tata naskah, komunikasi kerja, disiplin dan etika kerja, psikologis kerja, kepemimpinan dan pelaporan kerja.

4. Instruktur

Intruktur atau pelatih harus didasarkan pada keahlian dan kemampuannya untuk mentranformasikan keahlian tersebut pada peserta pelatihan.

5. Waktu Pelatihan

Waktu yang tepat untuk diadakannya sebuah pelatihan adalah ketika setiap diandakannya promosi atau mutasi jabatan, bahkan setiap dilakukannya rekruitmen karyawan agar dapat mengahasilkan tujuan maksimal.

6. Metode Pelatihan

Untuk melaksanakan pelatihan maka harus ditentukan metode atau cara penyampaian yang paling tepat. Pemilihan atau penentuan metode pelatihan tersebut didasarkan atas materi yang akan disajikan.

Selanjutnya, menurut Malayu Hasibuan (2010: 70) pelatihan merupakan suatu usaha untuk meningkatkan pengetahuan dan keahlian seorang karyawan dalam mengerjakan suatu pekerjaan. Apabila pelatihan diartikan sama dengan meningkatkan pengetahuan, maka dapat diartikan bahwa pengetahuan akan pekerjaan yang akan dilakukan, pengetahuan memahami 
sasaran kerja yang akan dicapai, serta memahami betapa pentingnya sikap disiplin dalam organisasi agar pekerjaan berjalan dengan baik. Senada dengan itu, Agnes Heni Triyuliana (2008: 117) mengemukakan bahwa pelatihan dapat membantu karyawan mempelajari keterampilan yang akan meningkatkan kinerja karyawan sehingga dapat membantu perusahaan atau organisasi mencapai sasarannya. Hal ini menunjukkan bahwa pelatihan mencakup pengetahuan, keahlian dan sikap yang harus dimiliki oleh sumber daya manusia (SDM) dalam sebuah organisasi sehingga berhasil dalam melaksanakan tugas-tugas yang diberikan.

Berdasarkan uraian mengenai konsep pelatihan di atas, dengan demikian dapat penulis simpulkan bahwa yang dimaksud dengan pelatihan adalah pengusahaan terhadap pengetahuan, keterampilan dan sikap yang sesuai dengan pekerjaan yang dibebankan kepada seseorang sehingga dapat mencapai hasil yang maksimal. Pelatihan mencakup beberapa aspek antara lain fasilitas, bahan pendukung, materi, instruktur, waktu dan metode. Konsep pelatihan seperti inilah yang digunakan dalam penelitian ini.

Banyak penelitian yang dilakukan oleh para peneliti tentang pengaruh pelatihan kerja terhadap kinerja seseorang atau kinerja suatu organisasi. Adapun temuan penelitian yang mendukung teori tersebut antara lain dibuktikan oleh hasil penelitian Sugiarti (2016), Ni Wayan Eka Sri Anggereni (2016), Andi Abdul Munir (2017), dan Daniel Arfan Aruan (2013) yang pada umumnya mendapatkan hasil penelitian bahwa variabel pelatihan berpengaruh secara signifikan terhadap kinerja
Email : jianfis.unp@gmail.com

Vol.2 No.1 Tahun 2019

pegawai atau karyawan dalam melaksanakan pekerjaan.

\section{Metode Penelitian}

Penelitian ini menggunakan metode penelitian kuantitatif. Dikatakan pendekatan kuantitatif dikarenakan pendekatan yang digunakan di dalam penelitian, proses, hipotesis, turun kelapangan, sampai dengan penulisannya menggunakan aspek rumus, pengukuran, perhitungan dan analisisnya menggunakan data numerik atau angka yang diolah dengan menggunakan metode statistik. Populasi dalam penelitian ini adalah seluruh aparatur pemerintah nagari yang ada pada seluruh kenagarian di Kabupaten Tanah Datar. Sedangkan sampel dalam penelitian ini berjumlah 248 responden yang ditentukan dengan menggunakan rumus Slovin dan dilakukan dengan teknik Multistage Random Sampling.

Data penelitian yang dikumpulkan dalam penelitian ini, dilakukan dengan menggunakan angket dengan pengukuran skala likert dan menggunakan 4 pilihan jawaban (sangat setuju, setuju, kurang setuju dan tidak setuju). Selanjutnya data yang diperoleh dianalisis dengan menggunakan teknik regresi linear berganda. Sebelum dilakukan uji regresi maka terlebih dahulu dilakukan uji asumsi klasik sebagaimana dipersyaratkan dalam uji regresi. Sementara untuk mendapatkan gambaran umum terkait dengan kedua variabel juga perlu digunakan frekuensi, mean dan TCR (Tingkat Capaian Responden).

\section{Hasil Penelitian dan Pembahasan}

Temuan Penelitian 
Sebagaimana telah dikemukakan dalam bagian pendahuluan di atas, penelitian ini akan menjawab pertanyaan penelitian atau rumusan masalah. Rumusan masalahnya adalah: apakah terdapat pengaruh pelatihan kerja (yang mencakup keenam sub variabel yaitu fasilitas, bahan pendukung, materi, instruktur, waktu dan metode secara bersama-sama) aparatur pemerintah nagari terhadap pengelolan keuangan nagari di Kabupaten Tanah Datar? Untuk menjawab pertanyaan penelitian ini dapat dilihat hasil analisis data temuan penelitian seperti disajikan pada Tabel 1 berikut.

Tabel 1. Pengaruh Pelatihan Kerja Aparatur Pemerintah Nagari (secara simultan) terhadap Pengelolan Keuangan Nagari

Model Summary ${ }^{b}$

\begin{tabular}{cccccc}
\multicolumn{6}{c}{ Model Summary } \\
\hline Model & $\mathbf{R}$ & R Square & Adjusted R Square & $\begin{array}{c}\text { Std. Error of the } \\
\text { Estimate }\end{array}$ & Durbin-Watson \\
\hline 1 & $.351^{\mathrm{a}}$ & .123 & .101 & .32882 & 1.843 \\
\hline
\end{tabular}

a. Predictors: (Constant), Metode, Waktu, Fasilitas, Materi, Instruktur, Bahan Pendukung

b. Dependent Variable: Rata-rata Pengelolaan Keuangan Nagari

Tabel 2. Hasil Uji Anova (F) Pengaruh Variabel Pelatihan Kerja Aparatur Pemerintah Nagari terhadap Pengelolaan Keuangan Nagari

ANOVA $^{b}$

\begin{tabular}{ccccccc}
\hline Model & $\begin{array}{c}\text { Sum of } \\
\text { Square }\end{array}$ & Df & Mean Squares & F & Sig \\
\hline 1 & Regression & 3.654 & 6 & .609 & 5.632 & $.000^{\mathrm{a}}$ \\
\cline { 2 - 7 } & 26.058 & 241 & .108 & & \\
\cline { 2 - 6 } & Residual & 29.711 & 247 & & & \\
\hline
\end{tabular}

a. Predictors: (Constant), Metode, Waktu, Fasilitas, Materi, Instruktur, Bahan Pendukung

b. Dependent Variable: Rata-rata Pengelolaan Keuangan Nagari

Berdasarkan Tabel 1 di atas dapat dijelaskan bahwa nilai Adjusted $R$ Square yang diperoleh dari analisis regresi sebesar 0,101. Artinya, besarnya pengaruh variabel pelatihan kerja aparatur pemerintah nagari secara simultan terhadap pengelolan keuangan nagari adalah adalah sebesar $10,1 \%$. Sementara sisanya sebesar $89,9 \%$ dipengaruhi oleh faktor lain yang tidak diteliti dalam penelitian ini. Dalam hal ini pelatihan kerja aparatur pemerintah nagari memiliki pengaruh signifikan terhadap pengelolaan keuangan nagari. Secara parsial nilai signifikansi variabel lebih kecil dari 0.05, maka Ho di tolak dan Ha diterima. Selain itu, jika diperhatikan hasil uji Anova pada Tabel 2 di atas dapat pula dilihat bahwa hasil atau angka signifikansi pengaruh menunjukkan angka $0,000^{\mathrm{a}}$. Artinya, kebenaran kesimpulan hasil hasil uji regresi ini dapat dipercaya sampai $100 \%$.

Selanjutnya, besaran pengaruh variabel pelatihan kerja aparatur pemerintah nagari secara parsial 


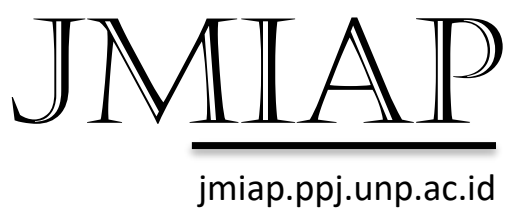

terhadap pengelolaan keuangan nagari
JURNAL ILMU ADMINISTRASI PUBLIK

Email : jianfis.unp@gmail.com

Vol.2 No.1 Tahun 2019

dapat dilihat pada Tabel 3 berikut ini:

Tabel 3. Pengaruh Sub Variabel Pelatihan Kerja Aparatur Pemerintah Nagari Secara Parsial terhadap Pengelolaan Keuangan Nagari

\begin{tabular}{lccrl}
\hline \multicolumn{1}{c}{ Sub Variabel } & \multicolumn{1}{c}{$\mathbf{R}$} & R Square & Adjusted R Square & Sig. \\
\hline Fasilitas & $.336^{\mathrm{a}}$ & .113 & .109 & $.000^{\mathrm{b}}$ \\
\hline Bahan Pendukung & $.261^{\mathrm{a}}$ & .068 & .064 & $.000^{\mathrm{b}}$ \\
\hline Materi & $.248^{\mathrm{a}}$ & .061 & .058 & $.000^{\mathrm{b}}$ \\
\hline Instruktur & $.209^{\mathrm{a}}$ & .044 & .040 & $.000^{\mathrm{b}}$ \\
\hline Waktu & $.112^{\mathrm{a}}$ & .013 & .009 & $.000^{\mathrm{b}}$ \\
\hline Metode & $.251^{\mathrm{a}}$ & .063 & .059 & $.000^{\mathrm{b}}$ \\
\hline
\end{tabular}

Berdasarkan Tabel 3 di atas dapat dipahami bahwa, nilai Adjusted $R$ Square untuk sub-variabel fasilitas adalah sebesar 0,109. Hal ini berarti bahwa pengaruh fasilitas terhadap pengelola keuangan nagari adalah sebesar $10,9 \%$ dan sisanya sebesar $89,1 \%$ dipengaruhi oleh variabel lain. Selanjutnya nilai Adjusted $R$ Square untuk sub-variabel bahan pendukung adalah sebesar 0,064. Hal ini berarti bahwa pengaruh bahan pendukung terhadap pengelola keuangan nagari adalah sebesar $6,4 \%$ dan sisanya sebesar 93,6\% dipengaruhi oleh variabel lain Sementara nilai Adjusted $R$ Square untuk sub-variabel materi adalah sebesar 0,058. Hal ini berarti bahwa pengaruh materi terhadap pengelola keuangan nagari adalah sebesar 5,8\% sedangkan sisanya sebesar 94,2\% dipengaruhi oleh variabel lain. Nilai Adjusted $R$ Square untuk sub-variabel instruktur adalah sebesar 0,040. Hal ini berarti bahwa pengaruh instruktur terhadap pengelola keuangan nagari adalah sebesar $4 \%$ dan sisanya sebesar $96 \%$ dipengaruhi oleh variabel lain. Sedangkan nilai Adjusted $R$ Square untuk sub-variabel waktu adalah sebesar 0,009. Hal ini berarti bahwa pengaruh waktu terhadap pengelola keuangan nagari adalah sebesar 0,9\% dan sisanya sebesar $99,1 \%$ dipengaruhi oleh variabel lain. Kemudian nilai Adjusted $R$ Square untuk sub-variabel metode adalah sebesar 0,059. Hal ini berarti bahwa pengaruh metode terhadap pengelola keuangan nagari adalah sebesar 5,9\% sedangkan sisanya sebesar 94,1\% dipengaruhi oleh variabel lain. Selain itu, jika diperhatikan hasil uji Anova pada hasil atau angka signifikansi pengaruh menunjukkan angka $0,000^{\mathrm{a}}$ untuk seluruh sub-variabel. Ini berarti bahwa kebenaran kesimpulan hasil uji regresi ini dapat dipercaya sampai $100 \%$. Kemudian, hasil rumusan hipotesis penelitian menghasilkan Terdapat Pengaruh Pelatihan Kerja Aparatur Pemerintah Nagari terhadap Pengelolaan 


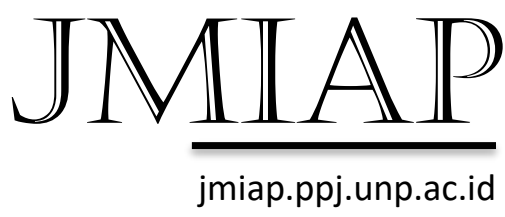

Keuangan Nagari di Kabupaten Tanah Datar.

\section{Pembahasan}

Hasil penelitian tentang pengaruh pelatihan kerja aparatur pemerintah nagari terhadap pengelolaan keuangan nagari di Kabupaten Tanah Datar telah membuktikan bahwa terdapat pengaruh pelatihan kerja aparatur pemerintah nagari dalam pengelolaan keuangan nagari di Kabupaten Tanah Datar, baik secara simultan maupun secara sendirisendiri dari keenam sub variabel pelatihan, yaitu fasilitas, bahan pendukung, materi, instruktur, waktu dan metode. Secara bersama-sama pengaruh fasilitas, bahan pendukung, materi, instruktur, waktu dan metode aparatur pemerintah nagari terhadap pengelolaan keuangan nagari di Kabupaten Tanah Datar menghasilkan angka signifikansi 0,000 dan nilai Adjust $R$ Square sebesar 0,101 sehingga dapat dikatakan bahwa kontribusinya adalah sebesar $10,1 \%$ dan nilai $\mathrm{R}$ sebesar $0,351^{\mathrm{a}}$ yang berarti bahwa kekuatan variabel pelatihan kerja aparatur pemerintah nagari terhadap pengelolaan keuangan nagari di Kabupaten Tanah Datar sebesar 35,1\%. Dengan demikian, berdasarkan penjelasan di atas dapat ditarik kesimpulan bahwa baik secara simultan maupun parsial pelatihan kerja aparatur pemerintah nagari memiliki pengaruh secara signifikan terhadap pengelolaan keuangan nagari di Kabupaten Tanah Datar.
JURNAL ILMU ADMINISTRASI PUBLIK

Email : jianfis.unp@gmail.com

Vol.2 No.1 Tahun 2019

Selanjutnya, hasil uji secara sendiri-sendiri pengaruh sub-variabel fasilitas (X1), bahan pendukung (X2), materi (X3), instruktur (X4), waktu (X5) dan metode (X6) terhadap pengelolaan keuangan nagari menghasilkan angka signifikansi masing-masing sebesar 0,000 dan nilai Adjust $R$ Square masingmasing sebesar $0,109(10,9 \%)$ untuk fasilitas, $0,064(6,4 \%)$ untuk bahan pendukung, 0,058 $(5,8 \%)$ untuk materi, 0,040 (4\%) untuk instruktur, 0,009 $(0,9 \%)$ untuk sub variabel waktu dan $0,059(5,9 \%)$ untuk metode. Oleh karenanya dapat dikatakan bahwa kontribusi fasilitas terhadap pengelolaan keuangan nagari sebesar $10,9 \%$, bahan pendukung sebesar $6,4 \%$, materi sebesar $5,8 \%$, instruktur sebesar $4 \%$, waktu sebesar $0,9 \%$ dan metode sebesar 5,9\%.

Dengan memperhatikan hasil penelitian ini dapat dipahami bahwa hasil penelitian ini dapat membuktikan dan ikut memperkuat teori-teori dan temuan penelitian yang sudah ada, seperti dikemukakan oleh Ivancevich (dalam Edy Sutrisno, 2009: 67) mengatakan bahwa pelatihan dapat meningkatkan kinerja karyawan dalam pekerjaannya sekarang atau dalam pekerjaan lain yang akan dijabatnya segera. Pelatihan yang baik tentu akan meningkatkan pengetahuan, kemampuan dan perilaku spesifik yang berkaitan dengan pekerjaan.

Hasil penelitian ini juga menukung teori yang dikemukakan oleh Wexley dan Yulk (dalam Edy Sutrisno, 2009: 67) bahwa pelatihan dapat meningkatkan produktifitas dan kepuasan kerja. Selain 
JMIAP

itu hasil penelitian ini juga mendukung dan memperkuat teori yang disampaikan oleh Soekidjo Notoatmodjo (2009: 19) bahwa pelatihan adalah suatu perubahan yang dapat meningkatakan kemampuan dan sasaran karyawan dalam melakukan pekerjaan.

Disamping itu, hasil penelitian ini juga ikut mendukung dan memperkuat teori yang dikemukakan oleh Campbell (dalam Mahmudi, 2015: 20) bahwa kinerja dipengaruhi oleh faktor pengetahuan, keterampilan yang diperoleh melaui pelatihan personel. Dari faktor-faktor tersebut yang mempengaruhi kinerja yang diungkapkan di atas dapat diketahui bahwa pelatihan merupakan faktor utama yang mempengaruhi kinerja.

Hasil penelitian ini juga mendukung dan berkaitkan dengan penelitian sebelumnya yang dilakukan oleh Sugiarti dkk (2016), Ni Wayan Eka Sri Anggereni (2016), Andi Abdul Munir dkk (2017), dan Daniel Arfan Aruan (2013) yang pada umumnya mendapatkan hasil penelitian bahwa variabel pelatihan berpengaruh secara signifikan terhadap kinerja pegawai atau karyawan dalam melaksanakan pekerjaan.

\section{Penutup}

Berdasarkan uraian hasil penelitian dan pembahasan di atas, dapat disimpulkan bahwa:
JURNAL ILMU ADMINISTRASI PUBLIK

Email : jianfis.unp@gmail.com

Vol.2 No.1 Tahun 2019

1. Variabel Pelatihan (X) terhadap Variabel Pengelolaan Keuangan Nagari (Y) secara simultan memiliki nilai Adjust $R$ Square $0,101 \%$ sehingga dapat dikatakan bahwa kontribusi pelatihan terhadap pengelolaan keuangan nagari di Kabupaten Tanah Datar sebesar 10.1\%. Dengan nilai signifikansiya lebih kecil dari 0,05, maka Ho di tolak dan Ha diterima

2. Secara simultan maupun parsial pengaruh pelatihan kerja aparatur pemerintah nagari terhadap pengelolaan keuangan nagari menunjukkan angka signifikansi 0,000. Dengan demikian dapat disimpulkan bahwa terdapat pengaruh yang signifikan variabel pelatihan kerja aparatur pemerintah nagari terhadap pengelolaan keuangan nagari di Kabupaten Tanah Datar dan kebenaran kesimpulan ini dapat dipercaya sampai dengan $100 \%$.

Berdasarkan hasil penelitian dan kesimpulan yang telah diuraikan di atas, adapun saran-saran yang dapat peneliti kemukakan sebagai berikut:

1. Hasil penelitian ini menunjukkan bahwa sub-variabel fasilitas, bahan pendukung, materi, instruktur, waktu dan metode aparatur pemerintah nagari berpengaruh secara signifikan terhadap pengelolaan keuangan nagari di Kabupaten Tanah Datar dengan kontribusi sebesar 10,1\%. Dengan demikian disarankan kepada setiap aparatur pemerintah nagari agar 
JMIAP

lebih memperhatikan dan mengikuti pelatihan yang mencakup aspek fasilitas, bahan pendukung, materi, instruktur, waktu dan metode dalam pengelolaan keuangan nagari. Walaupun pengaruhnya tidak terlalu besar (hanya 10,1), akan tetapi peningkatan pelatihan aparatur pemerintahan nagari dalam pengelolaan keuangan nagari ini perlu dilakukan untuk meningkatkan kinerja aparatur pemerintahan nagari secara keseluruhan.

2. Peneliti menyadari bahwa hasil penelitian ini masih memiliki kelemahan tertentu, maka dari itu diharapkan kepada peneliti selanjutnya untuk lebih menyempurnakan penelitian ini dengan melakukan penelitian yang lebih mendalam sekaligus menyertakan berbagai variabel lain yang memiliki pengaruh terhadap pengelolaan keuangan nagari di Kabupaten Tanah Datar.

\section{DAFTAR KEPUSTAKAAN}

Agnes Heni Triyuliana. (2008). Manajemen Sumber Daya Manusia. Yogyakarta: CV. Andi Offset.

Andi Abdul Munir, B. H. dan S. K. (2017). Pengaruh Pelatihan, Disiplin dan Motivasi Terhadap Kinerja Pegawai Pada Badan Pengelolaan Keuangan dan Aset Daerah Provinsi Sulawesi Tengah. Jurnal Katalogis, 5(3), 153-164. Retrieved

from
JURNAL ILMU ADMINISTRASI PUBLIK

Email : ¡ianfis.unp@gmail.com

Vol.2 No.1 Tahun 2019

http://jurnal.untad.ac.id/jurnal/index .php/Katalogis/article/view/8692/69 05

Anwar Prabu Mangkunegara. (2011). Manajemen Sumber Daya Manusia Perusahaan. Bandung: PT. Remaja Rosdakarya.

Daniel Arfan Aruan. (2013). Pengaruh Pelatihan Kerja dan Motivasi terhadap Kinerja Karyawan. Jurnal Ilmu Manajemen, 1(2). Retrieved from

http://jurnalmahasiswa.unesa.ac.id/i ndex.php/jim/article/view/3043

Edy Sutrisno. (2009). Manajemen Sumber Daya Manusia Edisi Pertama. Jakarta: Kencana Prenada Media Group.

Emron Edison dkk. (2016). Manajemen Sumber Daya Manusia. Bandung: CV. ALFABETA.

Husein Umar. (2002). Evaluasi Kinerja Perusahaan. Jakarta: PT. Gramedia Pustaka Utama.

Irham Fahmi. (2016). Manajemen Sumber Daya Manusia. Bandung: CV. ALFABETA.

Mahmudi. (2015). Manajemen Kinerja Sektor Publik. Yogyakarta: Sekolah Tinggi Ilmu Manajemen YKPN.

Malayu Hasibuan. (2010). Manajemen Sumber Daya Manusia. Jakarta: PT. Bumi Aksara. 
JMIAP

Muhammad Arif. (2007). Tata Cara Pengelolaan Keuangan Desa Dan Pengelolaan Kekayaan Desa. Pekanbaru: ReD Post Press.

Murtiono Yusuf. (2016). Modul Tata Kelola Keuangan Desa. Yogyakarta: Infest.

Ni Wayan Eka Sri Anggereni. (2016). Pengaruh Pelatihan Terhadap Kinerja Karyawan pada Lembaga Perkreditan Desa (LPD) Kabupaten Buleleng. Ejournal Jurusan Pendidikan Ekonomi, 10(2). Retrieved from https://ejournal.undiksha.ac.id/inde x.php/JJPE/article/view/12201

Peraturan Bupati Kabupaten Tanah Datar Nomor 11 Tahun 2014 Tentang Pedoman Pengelolaan Keuangan Nagari

Peraturan Daerah Kabupaten Tanah Datar Nomor 4 Tahun 2008 Tentang Nagari

Peraturan Menteri Dalam Negeri Nomor 113 Tahun 2014 Tentang Pedoman Pengelolaan Keuangan Desa

Peraturan Pemerintah Nomor 47 Tahun 2015 Tentang Desa

Rachmawati Ike Kusdyah. (2008). Manajemen Sumber Daya Manusia. Yogyakarta: CV. Andi Offset.
Rochmansyah
Soleh.
(2015).
Pengelolaan Keuangan Desa.
Bandung: Fokus Media.

UURAL ILMU ADMINISTRASI PUBLIK

Email : jianfis.unp@gmail.com

Vol.2 No.1 Tahun 2019

Soekidjo Notoatmodjo. (2009). Pengembangan Sumber Daya Manusia. Jakarta: PT. Rineka Cipta.

Sugiarti, T. H. dan H. A. (2016). Pengaruh Pelatihan Kerja Terhadap Kierja Karyawan pada PT. Padma Ardya Aktuaria Jakarta. Jurnal Epigram, 13(1). Retrieved from https://ejournal.undiksha.ac.id/inde x.php/JJPE/article/download/12201/ 7747

Syamsir. (2017). "Model Pembinaan Kapasitas Aparatur Pemerintah Nagari dalam Pengelolaan Keuangan Nagari di Kabupaten Tanah Datar Provinsi Sumatera Barat". Laporan Penelitian. Padang: Universitas Negeri Padang.

Undang-Undang Nomor 17 Tahun 2003 Tentang Keuangan Desa

Undang-Undang Nomor 23 Tahun 2014 Tentang Pemerintah Daerah

Undang-Undang Nomor 6 Tahun 2014 Tentang Desa

Warta Andalas. (2015). Wali Nagari Sunggayang Di Duga Tersandung Kasus Penggelapan Dana Nagari. Retrieved from http://wartaandalas.com/berita-walinagari-sungayang-di-duga tersandung-kasus-penggelapandana-nagari.html

Wibowo. (2011). Manajemen Kinerja 


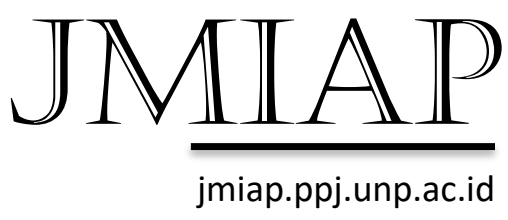

JURNAL ILMU ADMINISTRASI PUBLIK Email : ¡ianfis.unp@gmail.com Vol.2 No.1 Tahun 2019

Edisi Ketiga. Jakarta: PT Raja
Gravindo Persada. 